\title{
White Garden Snail, Theba pisana (Mueller) (Gastropoda: Helicidae) ${ }^{1}$
}

Jane E. Deisler and Lionel A. Stange ${ }^{2}$

\section{Introduction}

The white garden snail, Theba pisana (Mueller), is the worst potential agricultural pest of the helicid snails introduced to North America (Mead 1971). It is the most frequently intercepted foreign land snail (Hanna 1966, Mead 1971), generally arriving in shipments from the Mediterranean countries. Theba pisana shows a strong proclivity for climbing up and into freight for aestivation and is difficult to detect. This snail can survive long and arduous journeys because of its ability to form a wall of dried mucus, called an epiphragm, in the aperture of its shell which reduces water loss during dormancy. Theba pisana is capable of explosive reproductive rates where it has been introduced, and can be found in densities of up to 3000 snails per tree (Mead 1971) after periods of less than 5 years (Chace 1915, Orcutt 1919). Once established, T. pisana causes severe defoliation of a number of plants, including citrus and ornamental plantings (Orcutt 1919, Pilsbry 1939, Abbott 1950, Dekle 1962, Hanna 1966, Mead 1971). Theba pisana was previously known as Helix pasana (Mueller).

\section{Distribution}

T. pisana is native in southwestern England and Wales, Ireland, western France, Switzerland, and the Mediterranean countries of Europe and Africa (Pilsbry 1939, Burch 1960). Its habitat in Europe is near the costs (Kerney and Cameron 1979). It has been introduced into the Atlantic islands, South Africa, Somaliland, and western Australia. This snail was first noticed in North America in La Jolla, San Diego County, California, in 1914 (Chace 1915, Basinger 1923). It soon spread to several locations in Orange and Los Angeles Counties, but apparently was eradicated there by 1940 (Hanna 1966). Mead (1971) reported a second infestation in Los Angeles County in 1966 which was declared eradicated in 1972 (William A. Edwards, personal communication). The snails were found and identified in August 1985 in San Diego, California, at several localities in about a 10 square mile area. Hanna (1966) stated that $T$. pisana has been introduced into several eastern localities in the United States. There are no published records for North American populations outside of California. Theba pisana is also present in Bermuda but has never been recorded from Florida.

1. This document is EENY-197 (originally published as DPI Entomology Circular 2), one of a series of Featured Creatures from the Entomology and Nematology Department, Florida Cooperative Extension Service, Institute of Food and Agricultural Sciences, University of Florida. Published: March 2001. Revised August 2002. This document is also available on Featured Creatures Website at http://creatures.ifas.ufl.edu. Please visit the EDIS Website at http://edis.ifas.ufl.edu.

2. Jane E. Deisler, museum curator, Corpus Christi Museum, Corpus Christi, TX; and Lionel A. Stange, Florida Department of Agriculture and Consumer Services, Division of Plant Industry.

The Institute of Food and Agricultural Sciences (IFAS) is an Equal Employment Opportunity - Affirmative Action Employer authorized to provide research, educational information and other services only to individuals and institutions that function without regard to race, creed, color, religion, age, disability, sex, sexual orientation, marital status, national origin, political opinions or affiliations. For information on obtaining other extension publications, contact your county Cooperative Extension Service office. Florida Cooperative Extension Service / Institute of Food and Agricultural Sciences / University of Florida / Larry R. Arrington, Interim Dean 


\section{Identification}

The shell is subglobose with a moderately depressed spire. The adult shell has $51 / 2$ to 6 slightly convex whorls with shallow sutures. It is of medium size, ranging from 12 to $15 \mathrm{~mm}$ (rarely to 25) in diameter and 9 to $12 \mathrm{~mm}$ (rarely to 20) in height, and is opaque and moderately solid. The umbilicus is narrow and partially to entirely covered by an expansion of the columella. The aperture of the shell is rounded and lunate and only slightly oblique. The lip of the aperture is sharp and unreflected, but some specimens show a thickening inside the lip. The juvenile shell has a sharp keel at the periphery, but in the adult shell the periphery is only slightly shouldered. The surface of the shell is not glossy, but is marked with many fine vertical striae. The background color of the shell is nearly always ivory white (rarely pink), and there are often a variable number of narrow dark-brown spiral bands present. These bands may be solid, made up of dots and dashes, or absent. This difference in coloration does not have any systematic significance because it is apparently a polymorphic trait subject to differential selection pressures and it correlates with microhabitat (Johnson 1980). The first 1 1/2 whorls are generally dark in color, ranging from tan to dark brown, and give the appearance of a dot on the apex of the shell.

\section{Biology}

During dry weather, most slugs and snails aestivate hidden under logs or stones or buried in the earth. However, T. pisana aestivates in the open on trees, fences, and other vertical surfaces. Pilsbry (1939) reported that $T$. pisana mates after rains during early November in California. Like all helicid snails, Theba pisana is a cross-fertilizing hermaphrodite. The eggs are deposited several inches in the ground a few weeks after mating. Hatching occurs after a minimum of 20 days, but may occur later during dry weather. In the active season, this snail partially defoliates a variety of shrubs and trees, including citrus. The great density of the populations in California (up to 3000 snails per tree) and the rapid rate of reproduction are primary factors in making this snail a major pest (Mead 1971).
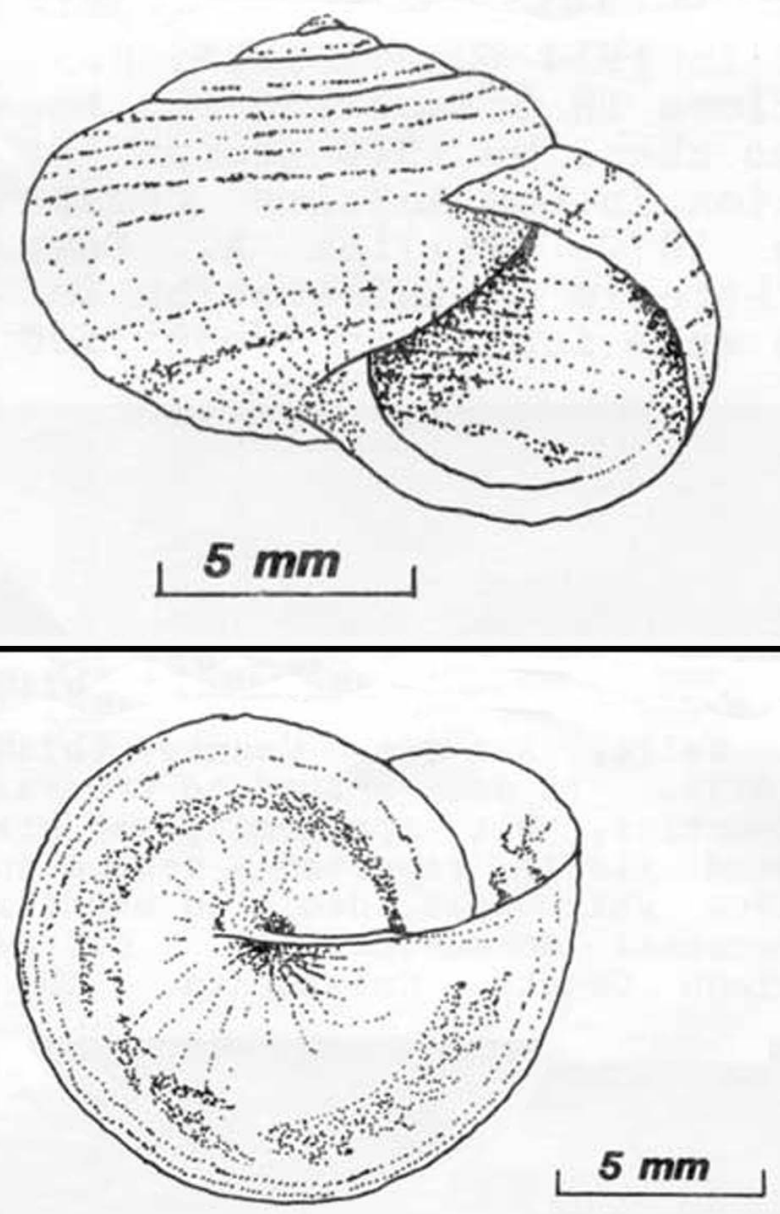

Figure 1. Front (top) and basal (bottom) views of the white garden snail, Theba pisana (Muller). Credits: Division of Plant Industry

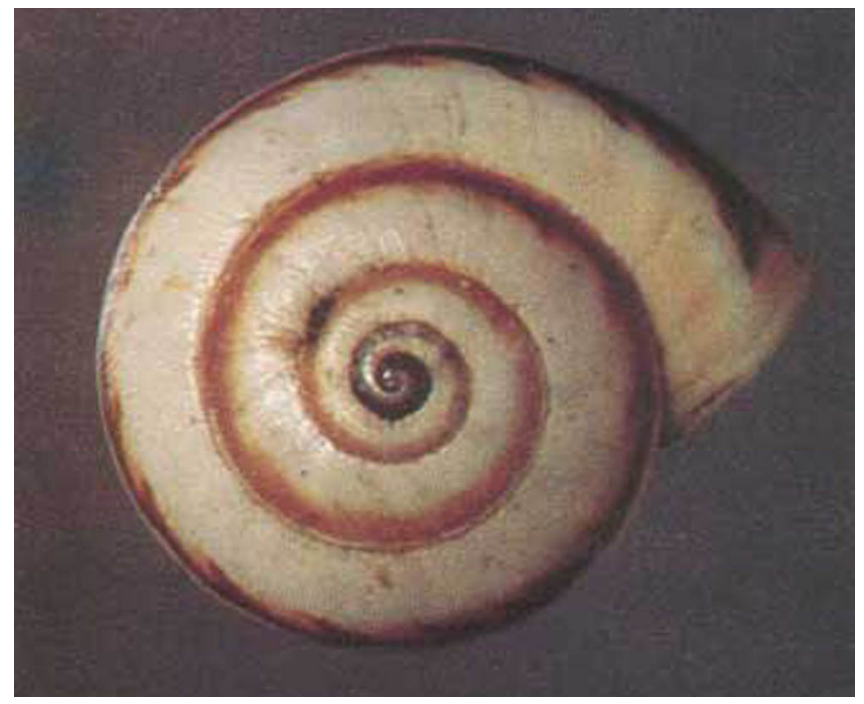

Figure 2. Brown banded color form of the white garden snail, Theba pisana (Muller). Credits: Division of Plant Industry 


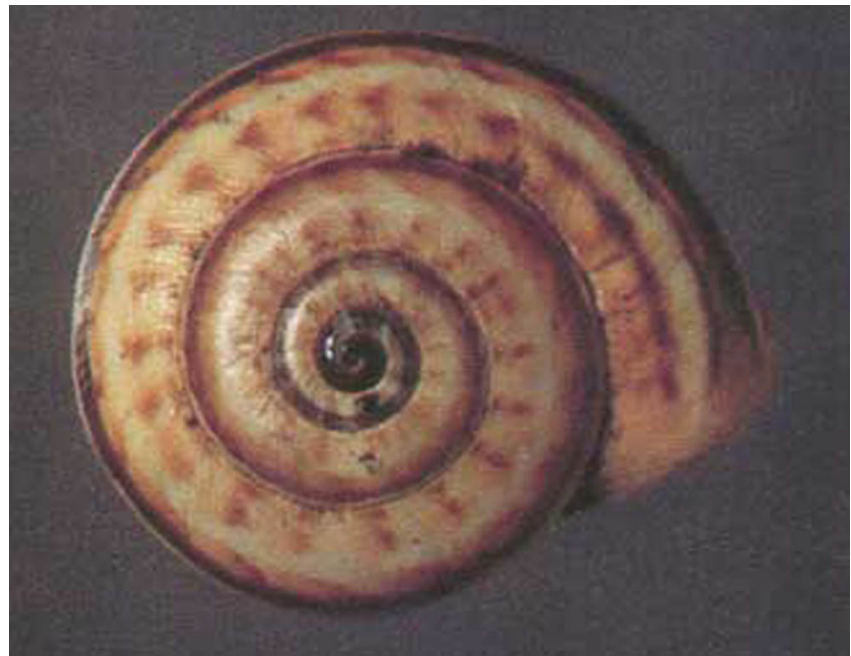

Figure 3. Dots and dashes color form of the white garden snail, Theba pisana (Muller). Credits: Division of Plant Industry



Figure 4. A lighter dots and dashes color form of the white garden snail, Theba pisana (Muller). Credits: Paul M. Choate, University of Florida

\section{Survey and Detection}

Search should be directed to plants, fences, and other vertical surfaces in nature, especially in sandy areas. Crates shipped from areas where the snails are known to exist should be examined, especially the lids and corners.

\section{Management}

Past infestations of $T$. pisana in California have been controlled and eventually eradicated by the combined use of poison sprays, poison baits, burning,

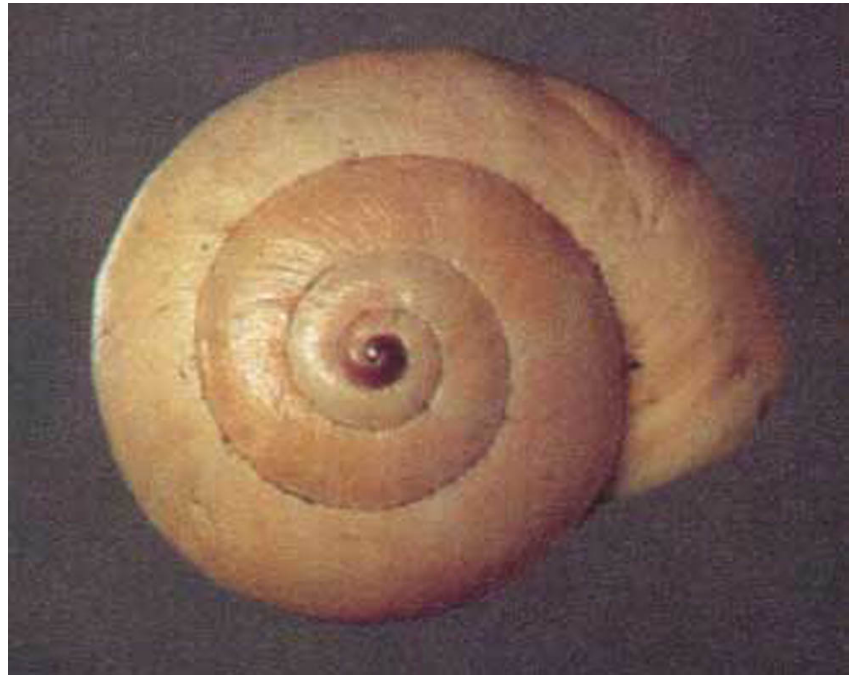

Figure 5. Non-banded color form of the white garden snail, Theba pisana (Muller). Credits: Division of Plant Industry

and hand-picking (Basinger 1927, Pilsbry 1939). These campaigns were invariably long and costly due, in part, to the way in which this snail hides itself for long periods by climbing up, on, and into bushes, trees, and man-made objects. Any control program in Florida would require the use of metaldehyde baits or bran-calcium in conjunction with detailed surveys of the ground, plantings, and structures within the infected areas. The use of herbicides may be necessary in overgrown areas. Mead (1971) recommends rigid quarantine and fumigation of all suspect shipments.

\section{Selected References}

Abbott, R.T. 1950. Snail invaders. Natural History 59: 80-85.

Anonymous. 1961. Interceptions of special interest at U.S. ports of entry. Coop. Econ. Insect Report 11: 50.

Basinger, A.J. 1923. A valuable snail poison. J. Econ. Entomol. 16: 456-458.

Basinger, A.J. 1927. The eradication campaign against the white snail (Helix pisana) at La Jolla, California. Monthly Bull. Calif. Dept. Agric. 16: 51-76.

Burch, J.B. 1960. Some snails and slugs of quarantine significance to the United States. Agric. Res. Serv. U.S. Dept. Agric. ARS 82-1. 
Chace, E.P. 1915. Helix pisana Mueller in

California. Nautilus 29: 72.

Dekle, G.W. 1962. A snail pest of citrus, Theba

pisana Mueller. Fla. Dept. Agric. and Cons. Ser., Div. Plant Industry, Entomol. Circ. 2:1.

Hanna, G.D. 1966. Introduced mollusks of western North America. Occ. Papers Calif. Acad. Sci. 48: $1-108$.

Johnson, M.S. 1980. Association of shell banding and habitat in a colony of a land snail Theba pisana. Heredity 45: 7-14.

Kerney, M.P., and R.A. Cameron. 1979. A field guide to the land snails of Britain and northwest Europe. William Collins Sons and Co., Ltd. London. $288 \mathrm{p}$.

Mead, A.R. 1971. Helicid land mollusks introduced into North America. The Biologist 53: 104-111.

Orcutt, H.A. 1919. Shells of La Jolla, California. Nautilus 33: 62-67.

Pilsbry, H.A. 1939. Land Mollusca of North America (north of Mexico). Acad. Nat. Sci. Philad. Monographs 3: 1-573.

Stefani, T. de. 1913. L' Helix pisana ei danni che puo arrecare agli agrumi. Nuovi Annali Agric.

Siciliana, N.S. 1. 